\title{
ESL Learners' Perceptions on English Subtitled Audio-Visual Materials
}

\author{
Farah Aina Anas', Nur Yasmin Khairani Zakaria1,2 \\ ${ }^{1}$ Faculty of Education, National University of Malaysia, Bangi, Malaysia \\ ${ }^{2}$ School of Educational Studies, Universiti Kebangsaan Malaysia, Gelugor, Malaysia \\ Email: fara hainaanas@gmail.com, yasminzakaria@ukm.edu.my
}

How to cite this paper: Anas, F. A., \& Zakaria, N. Y. K. (2019). ESL Learners' Perceptions on English Subtitled AudioVisual Materials. Creative Education, 10, 2796-2803.

https://doi.org/10.4236/ce.2019.1012206

Received: October 21, 2019

Accepted: November 25, 2019

Published: November 28, 2019

Copyright $\odot 2019$ by author(s) and Scientific Research Publishing Inc. This work is licensed under the Creative Commons Attribution International License (CC BY 4.0).

http://creativecommons.org/licenses/by/4.0/

\begin{abstract}
This study was aimed to study ESL learners' perceptions on English subtitled audio-visual materials. The study used a mixed-method with the usage of both questionnaire survey and interview to provide insight into perceptions of this particular group of learners on English subtitled audio-visual materials. Study participants consisted of 30 Form Four ESL learners of randomly distributed academic performance and five teachers from the same school who are also their own English language teachers. A survey was conducted among these students to gauge their perceptions towards the use of audio-visual materials for language learning. SPSS was used for the statistical analyses. The study shows that audio-visual materials are highly accepted among these learners as they make use of its benefits in both inside and outside of classroom. Students did not find English subtitles as distracting and determined that it helps them in learning the language itself. Majority of students in this particular group agreed that they can understand better with the presence of English subtitles provided below. This study also investigated teachers' perspectives in the use of English subtitles in audio-visual materials. Generally, it can be concluded that, teachers highly appreciated the benefits of having audio-visual materials for a better language learning experience but determined to say that it is extremely vital to carefully choose the suitable materials to be used according to students' needs and proficiency level. This study contributes to teaching English mainly in daily schools across the country by suggesting that teachers should consider using this method during their lesson and the materials should always undergo review to ensure appropriateness.
\end{abstract}

\section{Keywords}

ESL, Audio-Visual Materials, English Subtitles

\section{Introduction}

Audio-visual materials are defined as training or educational materials directed 
at both the senses of hearing (audio) and sight (visual), that is films, recoding, photographs etc. used in classroom instructions, library collections, or the likes. While subtitles are words shown at the bottom of a film or television picture to explain what is being said.

Back in the previous time, learning a new language is basically only for the sake of looking at the literature part of that particular language (Cakir, 2006). Malaysia is not an exception as we have acknowledged the importance of proficiency in a third language in order to develop human capital that drives the k-economy as well as competes in the international arena (Zubairi \& Sarudin, 2009). The English Language has always played a significant role in Malaysia's quest of becoming a developed nation (Ming, Ling, \& Mohd Jaafar, 2011). However, in this present time, the necessity of learning a new language has become a communicative need among the learners which covers a lot more than just a written input. Since subtitled films or videos are the combination of three mediums: aural, visual and textual (Rokni \& Ataee, 2014), it is basically the reason why they believe that watching films in English with subtitles could be one of the richest ways of presenting authentic input.

We got to admit that students do not tolerate pen and paper that much anymore hence making the teaching of a language is not an easy task. It is crucial for teachers these days to make the learning experience as interesting as possible, as the anxiety will always be there especially in learning a second or foreign language. Hence, with the rapid growth and availability of technology, language teachers these days are incorporating different additional aids along with the textbooks provided to teach this complex component in order to create innovative and interesting lessons. Innovations in computer technology have made possible new platforms for supporting and building shared knowledge in meaningful and creative ways to enhance language learning and acquisition (Krish et al., 2011).

\section{A Brief Literature Review to Audio-Visual Materials}

Shabiralyani et al. (2015) in their study concluded that using visuals aids as a teaching method stimulates thinking and improves the learning environment in a classroom. Their study also found out that the effective use of visual aids substitutesmonotonous learning environments and the students find visual aids sessions as useful and relevant when it has some direct relation to the course content.

Some characteristics of the audio-visual materials used in a study conducted by Aloqaili (2014) were thought to be supportive of a successful acquisition. These characteristics are first represented by the entertainment feature, which is linked to watching films that are thought to provide participants with a low anxiety learning environment, increase their motivation and positively affect their learning in general. The result indicated that the participants have positive attitudes toward learning from subtitled videos. The researcher also suggested 
that subtitled videos to be used as an effective learning tool in the second language classroom.

Alonso-Pérez \& Sánchez-Requena (2018) have conducted an interesting study where was aimed to discover the experience of teachers who have been using audio-visual translations techniques and their perspectives on in the combination of foreign language and audio-visual materials in the future. The varieties of the nationality of the teachers indicated that the results obtained are applicable to different languages. The study resulted in having the teachers who have been using these techniques have had excellent experiences as they find audio-visual translations to be a motivating and engaging tool not only for the students but for themselves as well. The researchers, however, questioned the teachers who are not as in favor of the usage of ICT in the language classroom to be lacking of knowledge about audio-visual translations resources.

Al Mamun (2014) conducted a study to find out how the use of audio-visual aids can facilitate language teaching and learning. It has been found out that both the teachers and the students show a favorable attitude toward the use of audio-visual aids agreeing that they facilitate language teaching and learning in diverse ways.

\section{Research Questions}

1) What are ESL learners' perceptions on English Subtitled audio-visual materials?

2) What are teachers' perspectives in using English subtitled audio-visual materials?

\section{Findings}

There are 16 questions in total that have been divided into three parts; Part 1, 2 and 3. Part 1 consists of 6 questions that ought to discover students' familiarity of having English subtitles while watching a film or TV programme and into what extent do English subtitles help them in grasping the meaning relied behind. Part 2 in other hand, was to investigate the usage of videos with English subtitles in classroom by their teacher and how do they actually feel about having English subtitles to help them throughout the lesson. Last but definitely not least is Part 3, in which to examine their thoughts on the ability of English subtitles in helping them assisting the other skills involved in language learning.

We can conclude that there are three statements with the highest mean.

Table 1 shows the frequency of item 14, where 22 (73.3\%) students chose strongly agree for the statement English subtitles can help me in learning the language which makes it the highest mean with $\mathrm{M}=4.7$ and $\mathrm{SD}=.534$. This is maybe due to the content they received from the media itself that tend to be rich enough to help them learn the language. There is a potential source of communicative and authentic L2 input that is rich enough can be found in audio-visual material (York, 2016). However, this possibility depends on the media whether 
Table 1. English subtitles help me in learning the language.

\begin{tabular}{cccc}
\hline & Frequency & Percent & Cumulative Percent \\
\hline Neutral & 1 & 3.3 & 3.3 \\
Agree & 7 & 23.3 & 26.7 \\
Strongly Agree & 22 & 73.3 & 100.0 \\
Total & 30 & 100.0 & \\
\hline
\end{tabular}

or not it is suitable for educational purposes. Around 7 (23.3\%) students chose to agree and only $1(3.3 \%)$ student chose neutral. Perhaps, he or she is one of the weaker students who do not even realize he or she is acquiring language enrichment while watching with English subtitles.

Table 2 shows the frequency of item 13, where 19 (63.3\%) students chose strongly agree for the statement English subtitles can help me with listening comprehension. This statement obtained $\mathrm{M}=4.6$ and $\mathrm{SD}=0.490$. The remaining $11(36.7 \%)$ students chose to agree. The possibility is that this group of students are in intermediate and beginner level and are weak in listening skills where requires additional information from the media in order to understand the content; which in this sense is the subtitles. Students with lesser listening skills depended more on subtitles (Kashen, 1996). Even for good students, if the speaker from the media was an Irish whose accent may bring difficulties to understand the content spoken, subtitles can become handy.

Table 3 shows the frequency for item 11, which 17 (56.7\%) students chose strongly agree for the statement I do not feel bored when watching the videos with English subtitles during the lesson and it hits the third highest with $\mathrm{M}=4.5$ and $\mathrm{SD}=.504$. The remaining $13(43.3 \%)$ students chose to agree. This result may due to the fact that the chosen audio-visual materials are already fun to watch in the very first place. Audio visual aids that are used in classrooms are the devices used to encourage teaching learning process in which making it easier and interesting (Saima et al., 2011). Having English subtitles just makes the experience becomes more enjoyable.

\section{Conclusions and Recommendations}

\subsection{Research Question One}

The current study explores the possible perceptions lingering around ESL learners' minds when it comes to having audio-visual materials with English subtitles. Inspired by past studies, in which had been proposed that there is a significant difference when subtitles are present in any kind of media used. Many of the previous studies have demonstrated positive outcomes when introducing subtitles in many aspects of the language, be it vocabulary enrichment, listening skills, speaking skills or reading comprehension. When most of the studies focusing on the effectiveness of the subtitles usage in audio-visual materials, this study ought to discover ESL learners' perceptions towards this particular method in language learning in either classroom or outside of the classroom. 
Table 2. English subtitles help me with listening comprehension.

\begin{tabular}{cccc}
\hline & Frequency & Percent & Cumulative Percent \\
\hline Agree & 11 & 36.7 & 36.7 \\
Strongly Agree & 19 & 63.3 & 100.0 \\
Total & 30 & 100.0 & \\
\hline
\end{tabular}

Table 3. I do not feel bored when watching the videos with english subtitles during the lesson.

\begin{tabular}{cccc}
\hline & Frequency & Percent & Cumulative Percent \\
\hline Agree & 13 & 43.3 & 43.3 \\
Strongly Agree & 17 & 56.7 & 100.0 \\
Total & 30 & 100.0 & \\
\hline
\end{tabular}

This study revealed that generally, ESL learners determined that English subtitles do play an important role in helping them learn the language itself. It is the fact that subtitles are authentic and rich enough to make the language learning possible with or without their consent. However, the researcher believes that the maximum success of learning can only be achieved with the learners already aimed to do so beforehand. This is by saying that, only if there is a specific task assigned by the teacher that will have them to be extra focus while watching the videos or any kind of audio-visual materials.

This study also discovered that the learners are determined that listening comprehension capability is possible to be enhanced with the presence of English subtitles. The researcher finds that weak students will make use of this method the most as they do feel the need of having extra input to avoid feeling demotivated throughout the lesson. Nothing is more frustrating than not having a full understanding of what we are watching. However, this result is contradicted with the fact that they do not feel that English subtitles make watching a film or TV programme less challenging.

The researcher proposed an argument where the choice of the materials itself is already hard for the students to comprehend that even the subtitles do not do any help in making the learning process any easier. Moreover, the result is also may be due to the difference in students' proficiency level where the weaker ones need extra guidance from the teacher since the subtitles do not help as it should be. Another result obtained from this study is that ESL learners' do not feel like English subtitles distract them from watching at all. However, there is a slight difference between those who determined that English subtitles can help them in understanding the content better with those who feel the hesitation.

The researcher suggested that perhaps the selection of media itself does not help in promoting better understanding from the very first place. If the content contains heavy and unfamiliar words, the moment the students read the subtitles, they already feel demotivated as their vocabulary is not rich enough to fit 
the input from the media. Motivation and attitude are the two elements which are fundamental in learning a second language as well as to provide the continuity needed to carry on the learning process (Mohd Shah \& Abdullah, 2014). Apart from that, it is certain that ESL learners' find English subtitled audio-visual materials as interesting and fun to watch. This statement is supported by many of previous studies that suggested that the idea of bringing in audio-visual materials is to make the learning session a lot more interactive.

Most of the observations made in the studies discovered that students were more attentive in the classroom as they engaged well to the media presented. This is aligned to the core purpose of having audio-visual materials in the classroom which to make an enjoyable learning experience for the students. They should never feel bored in the classroom as if they are experiencing an ordinary learning session.

\subsection{Research Question Two}

The results obtained in looking at teachers' perspectives on the use of English subtitled audio-visual materials are varied. However, it can be concluded that the teachers are comfortable in having audio-visual materials to aid their lesson in the classroom. There is no hesitation in the effectiveness of using this method to provide a better learning experience for the students. They emphasized that this method breaks the barrier of not providing enough picture to the abstract contents, especially for literature. They look at audio-visual materials as an amazing tool to bring the outside world to the small limited space of the classroom. However, the teachers are determined that the process of selecting the materials is crucial with the fact that the students' proficiency level differs from one another. Finding suitable materials to fit 30 students in one single classroom is not an easy task. It is vital for the materials to fit the needs of each and every one of them during the lesson. This aspect is supported in some studies in which the idea of giving extra attention to the selection of the media. However, these teachers are hesitating in the usage of English subtitles with the audio-visual materials though some said English subtitles help the students with a better sentence structure and the acquisition of new vocabulary is possible as they find that it is distracting the students from the actual purpose of the lesson.

It can be concluded that those who refused to have subtitles in their media chosen is because they feel like the students will be busy focusing on reading the subtitles rather than watching the media itself. The researcher's argument is that it is possible to have the students to watch the media twice or more. It is vital for the teacher to clearly instruct the students on what to do to avoid their concern on not having them focusing on watching the media. Teachers can always have two versions of the video; one with the subtitles and one without the subtitles. The teacher may start the lesson by emphasizing the need of watching the video without the subtitles first. The second time of watching it with the subtitles, the teacher may have the students to focus on the presence of it wisely. Watching the video twice is already give them a better understanding, but with the subtitles 
provided, those weaker groups of students will find it very helpful. This drives the conclusion of this study back to the necessity of getting the right and suitable materials before the lesson. Pre-activities may also become handy especially for weak students when the content is too heavy and difficult to comprehend in a short amount of time. Teachers should be aware of the time needed to be spent on preparing the materials to ensure the maximum success of the lesson.

The results obtained also cover the possible ways to overcome the challenges that commonly been faced by the teachers when using audio-visual materials for their aids. It can be concluded that it is crucial to create multiple levels of questions and materials based on the visual aid used. This is to ensure that every level of proficiency could be tested regardless of the level of difficulty of the media itself. Plus, pairing up proficient and less proficient students will also help in lessening the hardship faced by the teacher in having a different level of students' proficiency in class. Sometimes, students are more comfortable in having their own friends to peer-coaching them especially in the subjects they know they are weak in. Moreover, improvisations here and there where necessary are expected as it is best for teachers to have pre-lesson to put a benchmark on what can be predicted from the materials. The educators need to vary their teaching methods in order to cater to the needs of the students (Maarof \& Munusamy, 2015).

This study has found out that it is best to have this extended especially for Malaysian context as there are hundreds of studies conducted outside of the country that explored more on the effectiveness of having subtitles in audio-visual materials. The future study required pre and post-test in order to see whether or not there is a significant difference between audio-visual materials that are with or without subtitles.

\section{Funding}

This research is supported by Universiti Kebangsaan Malaysia under research "Dana Penyelidikan FP end" scheme no. (i) GG-2019-006 and PP-FPEND-2019.

\section{Conflicts of Interest}

The authors declare no conflicts of interest regarding the publication of this paper.

\section{References}

Al Mamun, M. A. (2014). Effectiveness of Audio-Visual Aids in Language Teaching in Tertiary Level Effectiveness of Audio-Visual Aids in Language Teaching in Tertiary Level. Unpublished Master's Thesis.

Alonso-Pérez, R., \& Sánchez-Requena, A. (2018). Teaching Foreign Languages through Audiovisual Translation Resources: Teachers' Perspectives. Applied Language Learning, 28, 1-24.

Aloqaili, G. S. (2014). Learning Vocabulary from Subtitled Videos: An Investigation into the Effectiveness of Using Subtitled Videos for Intentional Vocabulary Learning in Saudi Arabia with an Exploration of Learners' Perspective. 
Cakir, I. (2006). The Use of Video as an Audio-Visual Material in Foreign Language Teaching Classroom. The Turkish Online Journal of Educational Technology, 5, 67-72.

Kashen, J. E. (1996). First Language Subtitles: Help or Hindrance? Washington DC: Institute of Education Sciences.

Krish, P., Hussin, S., \& Sivapuniam, N. (2011). Language Learning and Language Acquisition in Online Forums. The Southeast Asian Journal of English Language Studies, 17, 91-100.

Maarof, N., \& Munusamy, I. M. (2015). Learner's Learning Experiences \& Difficulties towards (ESL) among UKM Undergraduates. Advances in Language and Literary Studies. Advances in Language and Literacy Studies, 6, 83-87. https://doi.org/10.7575/aiac.alls.v.6n.3p.83

Ming, T. S., Ling, T. S., \& Jaafar, M. N. (2011). Attitudes \& Motivation of Malaysian Secondary Students towards Learning English as a Second Language: A Case Study. The Southeast Asian Journal of English Language Studies, 17, 40-45.

Mohd Shah, P., \& Abdullah, H. I. (2014). Motivation and Attitudes towards Learning English among Undergraduates in National University of Malaysia (UKM). International Journal of English and Education, 3, 209-277.

Rokni, S., \& Ataee, A. (2014). The Effect of Movie Subtitles on EFL Learners' Oral Performance. International Journal of English Language, Literature and Humanities, 1, 201-215.

Saima, R., Qadir, B., \& Shazia, B. (2011). A Study to Analyze the Effectiveness of Audio Visual Aids in Teaching Learning Process at University Level. Procedia-Social and Behavioral Sciences, 28, 78-81. https://doi.org/10.1016/j.sbspro.2011.11.016

Shabiralyani, G., Shahzad Hasan, K., Hamad, N., \& Iqbal, N. (2015). Impact of Visual Aids in Enhancing the Learning Process Case Research. Journal of Education and Practice, 6, 226-234.

York, E. U. (2016). Effects from Using Subtitled Audiovisual Materials in Second Language Acquisition: An Experimental Study in a Second Language Learning Classroom in Norway.

Zubairi, A. M., \& Sarudin, H. I. (2009). Motivation to Learn a Foreign Language in Malaysia. Journal of Language Studies, 9, 73-87. 